\title{
The Inhibitory Action of $\alpha$-Methylmethionine on Escherichia coli
}

\author{
By R. J. ROWBURY \\ Botany Department, University College, London
}

(Accepted for publication I3 December 1967)

\begin{abstract}
SUMMARY
$\alpha$-Methylmethionine is a potent growth-inhibitory analogue of methionine producing an immediate effect on the growth rate of Escherichia coli at very low concentrations. Under certain conditions inhibition was transient, apparently due to an adaptation by the organisms. The analogue did not repress the synthesis of the methionine-forming enzymes but mimicked methionine as a feedback inhibitor of homoserine- $O$-trans-succinylase, acting on the enzyme at even lower concentrations than did methionine itself. Comparison of the effects on enzyme activity and growth rate leads to the conclusion that such enzyme inhibition is the basis of the effect of analogue on growth. Certain other compounds related to methionine also inhibited homoserine- $O$-trans-succinylase and of these D-methionine, DL-homocysteine and $\mathrm{N}$-acetylmethionine probably caused inhibition after conversion to L-methionine.

$\alpha$-Methylmethionine markedly inhibited the formation of infective phage after irradiation of $E$. coli $\mathrm{HfrH}(\lambda)$; methionine annulled the effect and allowed phage development to occur. The analogue was not incorporated into proteins in place of methionine, nor did it interfere with the incorporation of added methionine. Protein synthesis was inhibited by the analogue only when the process was dependent on methionine formation.
\end{abstract}

\section{INTRODUCTION}

Amino acid analogues produce inhibitory effects in a number of different ways. Competition with the normal amino acids either for incorporation into protein, or in some other key metabolic reaction, frequently occurs. Thus the phenylalanine analogue, $p$-fluorophenylalanine, the methionine analogues norleucine and ethionine and the histidine analogue triazolealanine all readily replace the natural amino acids in proteins (Richmond, 1960; Munier \& Cohen, 1959; Gross \& Tarver, 1955; Levin \& Hartman, 1963), although the methionine analogues may also influence other key reactions such as transmethylations (Lewis, 1963). Analogues may also mimic a natural metabolite in a regulatory feedback reaction and therefore interfere with metabolite synthesis. Thus the histidine analogue thiazolealanine (Moyed, 196I) mimics histidine as a feedback inhibitor of phosphoribosyl-ATP pyrophosphorylase, and 8-azaguanine mimics guanine as a repressor of the synthesis of the purine-forming enzymes (Levin \& Magasanik, 1959).

Much work has been described in which the methionine analogues norleucine and ethionine were used; the present work describes the inhibitory effect of another analogue $\alpha$-methylmethionine which appears to mimic the feedback effect of methio- 
nine. These observations form part of a wider study on the mechanism of analogue inhibition and resistance to inhibition (Lawrence, Smith \& Rowbury, 1967).

\section{METHODS}

Organisms. The auxotrophic strains of Escherichia coli used were maintained and subcultured as described previously (Rowbury \& Woods, I966). Strain PA I5 requires serine or glycine for growth and strain $7 / 9$ responds to methionine, homocysteine or cystathionine. Strains $\mathrm{HfrH}(\lambda)$ (obtained from Dr W. Hayes) and CLA (obtained from Dr G. Bertani) are prototrophic.

Organisms for growth experiments and for the preparation of enzymic extracts were grown on medium GL (Rowbury \& Woods, I964) supplemented with L-serine (mM) for strain PA 15 or DL-homocysteine $(0.2 \mathrm{mM})$ for strain $7 / 9$. Growth conditions and the preparation of enzymic extracts were as described previously (Rowbury \& Woods, I964).

Growth tests. For testing the effect of $\alpha$-methylmethionine and other analogues on the growth of Escherichia coli strain PA 15 from small inocula, tubes containing $4 \mathrm{ml}$. medium GL with L-serine ( $\mathrm{mM}$ ) and appropriate amounts of analogue were sterilized and after seeding with $0.1 \mathrm{ml}$. of organism suspension (equiv. $0.3 \mathrm{mg}$. dry wt/ml.) incubated in a sloped position at $37^{\circ}$ for 16 or $40 \mathrm{hr}$. Growth was assessed by using the EEL photoelectric colorimeter (Evans Electroselenium Ltd., Halstead, Essex).

For studying the growth of cell suspensions, washed organisms equiv. $0.05 \mathrm{mg}$. dry $\mathrm{wt} / \mathrm{ml}$. were incubated with shaking (Rowbury \& Woods, 1964) at $37^{\circ}$. Samples were removed at $30 \mathrm{~min}$. intervals and growth assessed with a Unicam SP 600 at $620 \mathrm{~m} \mu$.

Enzyme assays. Homocysteine methylase and homoserine- $O$-trans-succinylase were assayed in intact organisms as described previously (Rowbury \& Woods, I964, 1966); cystathionase and cystathionine synthetase were measured in ultrasonic extracts (Rowbury \& Woods, 1966).

Induction of $\lambda$ phage and phage assay. Escherichia coli $\mathrm{HfrH}$ carrying prophage $\lambda$ was grown in medium GL overnight, harvested, washed, resuspended in fresh medium GL and grown with shaking at $37^{\circ}$ for $2 \mathrm{hr}$ to obtain logarithmically growing organisms. Batches ( $5 \mathrm{ml}$.) of such cultures were then irradiated for $50 \mathrm{sec}$. (Phillips 6 Watt TUV lamp $95 \%$ emission at $2537 \AA$ at $\mathbf{2} 2$ in. from culture) to induce the prophage. Irradiated organisms were incubated with shaking for a further $2 \mathrm{hr}$ to allow phage development, chloroform (I0\%, $/ v$ ) being then added to bring about lysis. After removal of the chloroform by bubbling with air, suitable dilutions were plated with indicator bacteria ( $E$. coli strain CLA) in a soft agar overlay to estimate the number of effective phage particles.

Uptake of phenylalanine by organisms. Organisms of Escherichia coli strain PA I 5 or strain $7 / 9$ grown as previously described were incubated (equiv. I mg. dry wt organisms $/ \mathrm{ml}$.) in $2 \mathrm{ml}$. of medium previously used for methionine assays with Streptococcus equinus (see Gibson \& Woods, 1960) diluted r/4. ${ }^{14} \mathrm{C}$-phenylalanine $(0.5 \mu \mathrm{c} / \mathrm{ml}$., uniformly labelled, obtained from the Radiochemical Centre, Amersham, Buckinghamshire), was also added together with appropriate amounts of $\alpha$-methylmethionine. Incubation was for $1.5 \mathrm{hr}$, after which period organisms were heated in a boiling water bath for Io min. Organisms were harvested by centrifugation, washed twice on the centrifuge, taken up in $2 \mathrm{ml}$. water and the radioactivity assessed by spotting samples 
on ground-glass discs. A mica end-window Geiger-Müller tube (General Electric type 2 B 2) was used in conjunction with a Scaler 1700 of Isotope Developments Ltd., Reading, Berks.

Chemicals. The chemicals used were as described previously (Rowbury \& Woods, 1966).

\section{RESULTS}

The effect of $\alpha$-methylmethionine on the growth of Escherichia coli

When tested on the growth of Escherichia coli strain PA I5 from small inocula, $\alpha$-methylmethionine was far more potent an inhibitor than ethionine or norleucine. Growth was completely inhibited by $3 \mu \mathrm{M} \alpha$-methylmethionine, whereas $0 \cdot \mathrm{I}-\mathrm{I} \cdot 0 \mathrm{mM}$ was needed for full inhibition by the other analogues. The effect of $\alpha$-methylmethionine was completely annulled by equimolar amounts of methionine or cystathionine, but greater amounts of homocysteine were required to restore normal growth. Homoserine, an earlier methionine precursor, also annulled analogue inhibition.

The effect of $\alpha$-methylmethionine was also tested with Escherichia coli strain $7 / 9$ which is blocked in cystathionine formation. When these organisms were grown on

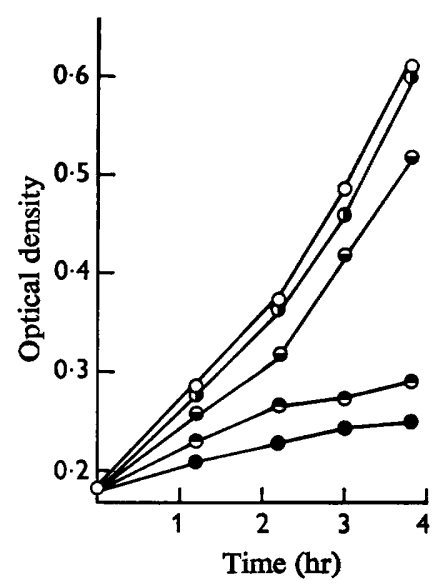

Fig. 1

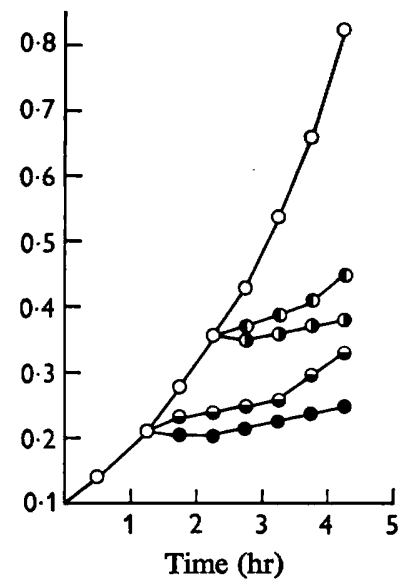

Fig. 2

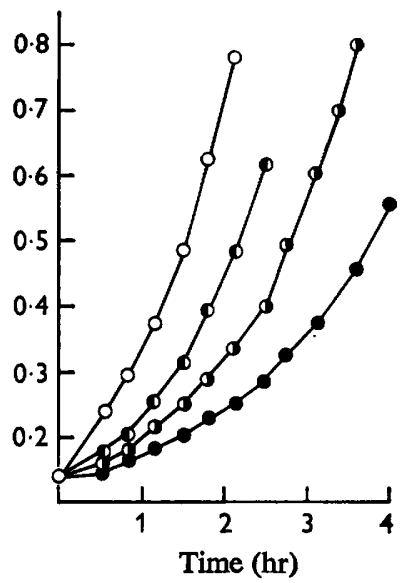

Fig. 3

Fig. I. The effect of $\alpha$-methylmethionine on the growth of washed suspensions of Escherichia coli strain PA 15. Organisms grown on GL medium + serine (mM) were resuspended in fresh medium (+ serine) with shaking at $37^{\circ}$. Growth was measured as described in Methods. $O$, Control culture, no analogue added;, $20 \mu \mathrm{M}-\alpha$-methylmethionine added at zero time; , $20 \mu \mathrm{M}-\alpha$-methylmethionine and $20 \mu \mathrm{M}$-DL-methionine added at zero; $\theta, 20 \mu \mathrm{M}-\alpha$-methylmethionine $+20 \mu \mathrm{M}$-DL-cystathionine added at zero; $\theta, 20 \mu \mathrm{M}-\alpha$-methylmethionine $+20 \mu \mathrm{M}-$ DL-homocysteine added at zero.

Fig. 2. The effect of $\alpha$-methylmethionine added during growth of Escherichia coli strain PA I 5 . Organisms grown as for Fig. I were resuspended in fresh medium ( + serine) and grown with shaking at $37^{\circ}$. $O$, Control culture, no analogue added; $0,20 \mu \mathrm{M}-\alpha$-methylmethionine

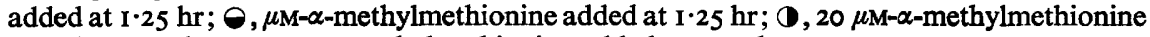
added at $2.25 \mathrm{hr} ; \mathrm{O}, \mu \mathrm{M}-\alpha$-methylmethionine added at $2.25 \mathrm{hr}$.

Fig. 3. The effect of low concentrations of analogue on the growth of washed suspensions. Organisms (Escherichia coli strain PA I5) grown in medium GL + serine, were resuspended in fresh medium (+ serine) and grown at $37^{\circ}$ as for Figs. I and 2. $O$, control culture, no analogueadded; $0,0.4 \mu \mathrm{M}-\alpha$-methylmethionine added at zero; $0,0.7 \mu \mathrm{M}$ - $\alpha$-methylmethionine

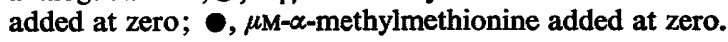


growth-limiting amounts of methionine, the analogue had only a slight inhibitory effect.

The effect of $\alpha$-methylmethionine was studied more closely with washed suspensions of Escherichia coli strain PA I 5. Analogue (20 $\mu \mathrm{M})$ added at zero time produced marked inhibition which again was readily annulled by methionine; cystathionine also restored growth, but homocysteine was ineffective unless higher concentrations $(0.3 \mu \mathrm{M})$ were used (Fig. I). $\alpha$-Methylmethionine was not only more potent than ethionine and norleucine but it acted more quickly; norleucine and ethionine produce gradual growth inhibition (Lawrence et al. 1967), but $\alpha$-methylmethionine stopped the growth of $E$. coli PA I 5 immediately it was added (Fig. 2). When lower concentrations of analogue were tested (either by addition initially or during exponential growth) it was observed that above $\mu \mathrm{M}$ the inhibition was almost complete and lasting but that between $0 \cdot \mathrm{I} \mu \mathrm{M}$ and I $\mu \mathrm{M}$ there was only a transient effect and the growth rate recovered almost to that of the control culture (Fig. 3). After growth in the presence of $\alpha$-methylmethionine organisms became partially adapted. Thus after growing with $\mathrm{I} \cdot 2 \mu \mathrm{M}$ analogue, washed suspensions grew better on low amounts of analogue than did control suspensions (Table r), although partial growth inhibition occurred.

Table I. Adaptation of Escherichia coli strain PAI5 to growth in presence of $\alpha$-methylmethionine

Organisms ( $E$. coli strain PA 15) were grown on minimal medium ( + serine) with $\alpha$-methylmethionine $(\mathrm{I} \cdot 2 \mu \mathrm{M})$ present (adapted culture) or absent (control culture). Washed suspensions of each culture were then suspended in minimal medium with the stated amount of analogue.

\begin{tabular}{lccc} 
& \multicolumn{3}{c}{ Mean generation time (min.) } \\
$\begin{array}{l}\text { In minimal minimal } \\
\text { medium } \\
+ \text { analogue } \\
(0.6 \mu \mathrm{M})\end{array}$ & $\begin{array}{c}\text { In minimal } \\
+ \text { analogue } \\
(0.9 \mu \mathrm{M})\end{array}$ \\
Control culture & II5 & 240 & 330 \\
Adapted culture & II5 & 143 & 207
\end{tabular}

The effect of $\alpha$-methylmethionine on the synthesis and activity of the methionine-forming enzymes of Escherichia coli

$\alpha$-Methylmethionine did not act by repressing the synthesis of the methionineforming enzymes because at growth inhibitory concentrations the amounts of the enzymes were somewhat increased ( $\mathrm{I} \cdot 5$ to 2 -fold); such increases may be responsible for the partial adaptation to the analogue (Table 1 ). These observations confirm the earlier view (Rowbury \& Woods, 196I) that the analogue was a poor repressor as compared to methionine even at $\mathrm{I}$ mM. When the analogue was tested for its effect on the activity of the methionine forming enzymes, it was observed that the first enzyme of the pathway (homoserine- $O$-succinylase) was very sensitive to inhibition; activity was decreased to $10 \%$ at $2 \mu \mathrm{M}$ analogue. The later methionine-forming enzymes were however quite unaffected by analogue even at I mM.

The effects of the analogue on growth and enzyme activity were compared by examining the initial growth rates of suspensions (Escherichia coli strain PA I5) and the homoserine- $O$-trans-succinylase activities of organisms $(E$. coli strain $7 / 9$ ) in the presence of a range of analogue concentrations. The analogue influenced the two processes very similarly (Table 2 ). The effect of $\alpha$-methylmethionine on the enzyme was 
in fact more marked than that of methionine itself. Thus methionine decreased activity to $50 \%$ at $8 \mu \mathrm{M}$, whereas analogue produced the same inhibition at $0.3 \mu \mathrm{M}$. Several other compounds structurally related to methionine were tested on homoserine- $O$ trans-succinylase. Ethionine and norleucine produced inhibitory effects only at high concentrations. Activity was very sensitive to the addition of D-methionine, DL-homocysteine and $N$-acetylmethionine, all of which produced $80-90 \%$ inhibition at $0.1 \mathrm{mM}$. Two growth-inhibitory compounds, norvaline and $S$-methylcysteine were also strong inhibitors, although much less so than $\alpha$-methylmethionine (Table 3 ).

Table 2. The effect of $\alpha$-methylmethionine on growth and on the activity of homoserine-O-trans-succinylase in Escherichia coli

For growth experiments, E. coli strain PA I5 was grown as described in Methods, harvested and resuspended (equiv: $0.05 \mathrm{mg}$. dry wt/ml.) in GL medium with the stated concentration of analogue. Growth was measured every $30 \mathrm{~min}$. For enzyme experiments $E$. coli strain $7 / 9$ was grown in GL medium, harvested and resuspended (equiv. $0.5-1.0 \mathrm{mg}$. dry wt/ml.) in fresh medium. Homoserine- $O$-trans-succinylase was assayed as described in Methods.

\begin{tabular}{|c|c|c|}
\hline \multirow{2}{*}{$\begin{array}{l}\text { Concentration of } \\
\text { analogue }(\mu \mathrm{M})\end{array}$} & \multicolumn{2}{|c|}{ Percentage of control } \\
\hline & Enzyme activity & Growth \\
\hline 0 & 100 & 100 \\
\hline $\begin{array}{l}0.3 \\
0.6\end{array}$ & $\begin{array}{l}51 \\
30\end{array}$ & $\begin{array}{l}55 \\
36\end{array}$ \\
\hline 0.9 & 23 & 23 \\
\hline $1 \cdot 2$ & 17 & 16 \\
\hline
\end{tabular}

Table 3. The effect of methionine and related compounds on the activity of homoserine-O-trans-succinylase of Escherichia coli strain 7/9

Organisms of $E$. coli strain 7/9 were grown in GL medium and homoserine-O-transsuccinylase assayed in the whole organisms as described in Methods with the stated additions.

\section{Additions (mM)}

None
DL- $\alpha$-methylmethionine (0.00I)
DL-Ethionine (0.5)
DL-Norleucine $(0.5)$
DL-Homocysteine (0.1)
D-Methionine (0.1)
$N$-Acetylmethionine (0.1)
DL-Norvaline (0.025)
DL-Norvaline (0.1)
DL-S-Methyl-cysteine (0.1)
DL-S-Methyl-cysteine (0.5)
L-Methionine (0.05)

Enzyme activity

(\% of control)

100
20
51
70
8
15
11
42
19
65
30
10

The effect of $\alpha$-methylmethionine on bacteriophage induction

Following ultraviolet irradiation of Escherichia coli $\mathrm{HfrH}(\lambda)$, incubation for about $2 \mathrm{hr}$ with shaking at $37^{\circ}$ allows development of the induced phage in minimal medium. $\alpha$-Methylmethionine $0.2 \mathrm{mM}$ added during this period decreased the formation of infective phage by a thousand-fold. Methionine (mM) almost completely annulled the effect (Table 4). 


\section{Analogue inhibition of phenylalanine incorporation}

Escherichia coli strain PA 15 incubated in a medium containing all the protein amino acids except methionine incorporated ${ }^{14} \mathrm{C}$-phenylalanine into the organisms. Such incorporation was inhibited by $\alpha$-methylmethionine; $\mu \mathrm{M}$ analogue led to $20 \%$ inhibition, Io $\mu \mathrm{M}$ to $65 \%$ inhibition, and $100 \mu \mathrm{M}$ to $80 \%$ inhibition. Inhibition was annulled by equimolar methionine. These results suggested that not only did $\alpha$-methylmethionine inhibit methionine formation but also that the analogue did not replace methionine in protein. This was further investigated by using a methionine-requiring strain ( $E$. coli strain 7/9). As expected this strain incorporated very little phenylalanine unless methionine was added. $\alpha$-Methylmethionine did not stimulate incorporation in the absence of methionine but ethionine, norleucine, homocysteine and cystathionine were all effective in place of methionine (Table 5).

Table 4. The effect of $\alpha$-methylmethionine on the induction of bacteriophage $\lambda$ in Escherichia coli

Logarithmically growing Escherichia coli $\mathrm{HfrH}(\lambda)$ was ultraviolet irradiated (see Methods) and incubated with shaking (with the stated additions) for $2 \mathrm{hr}$ at $37^{\circ}$. After lysis with chloroform, phage counts were done.

\begin{tabular}{|c|c|}
\hline Additions & $\begin{array}{l}\text { produced } \\
\text { particles/ml. culture }\end{array}$ \\
\hline $\begin{array}{l}\text { None } \\
\alpha \text {-Methylmethionine }(0.2 \mathrm{mM})\end{array}$ & $\begin{array}{l}3.2 \times 10^{9} \\
1.6 \times 10^{6}\end{array}$ \\
\hline a-Methylmethionine (Io mM) & $2.5 \times 10^{4}$ \\
\hline $\begin{array}{l}\alpha-\text { Methylmethionine }(0.2 \mathrm{mM})+\mathrm{DL}- \\
\text { methionine }(\mathrm{mM})\end{array}$ & $2.7 \times 10^{9}$ \\
\hline
\end{tabular}

Table 5. The effect of various methionine analogues on phenylalanine incorporation by Escherichia coli strain 7/9

Organisms of Escherichia coli strain 7/9 were incubated in $2 \mathrm{ml}$. of Streptococcus equinus medium (see Methods) with ${ }^{14} \mathrm{C}$-phenylalanine $(0.5 \mu \mathrm{c} / \mathrm{ml})$ and the stated additions. Incubation was for $\mathrm{I} \cdot 5 \mathrm{hr}$, after which the organisms were killed, washed and counted as described in Methods.

\begin{tabular}{|c|}
\hline $\begin{array}{l}\text { Phenylalanine } \\
\text { incorporated } \\
\text { counts/100 sec./2 ml } \\
\text { fluid }\end{array}$ \\
\hline 2,010 \\
\hline $\begin{array}{r}2,010 \\
16,110 \\
16,050\end{array}$ \\
\hline $\begin{array}{r}13,020 \\
11,160 \\
6,090\end{array}$ \\
\hline
\end{tabular}

\section{DISCUSSION}

The ability of methionine and biosynthetically related compounds to overcome inhibition by $\alpha$-methylmethionine shows that the latter is a methionine analogue. The immediate effect of the analogue on the growth of appropriate strains of Escherichia coli and its extreme potency as a growth inhibitor implied that it might influence 
processes quite different from those affected by ethionine and norleucine. It is attractive to consider that the inhibitory effect of the analogue is due to its similarity to methionine which causes blockage of homoserine- $O$-trans-succinylase. Concentrations of analogue which inhibit enzyme activity also inhibit or prevent growth. Feedback inhibition of this sort would be expected to produce an immediate effect on growth rate (due to an immediate limitation of methionine) as observed (Fig. 2), while at low concentrations of analogue, limitation of methionine would lead to enzyme derepression with gradual restoration of methionine synthesis, and therefore inhibition would be transient (Fig. 3). Such transient growth inhibition has been observed with the histidine analogue thiazolealanine which is a feedback inhibitor of histidine synthesis (Moyed, I96I). The observation that $E$. coli strain 7/9 (which cannot form cystathionine) was almost insensitive to inhibition is consistent with an effect of the analogue on cystathionine synthesis.

A parallel study with Salmonella typhimurium (Lawrence, et al. 1967) provides further evidence that $\alpha$-methylmethionine acts on growth by inhibiting homoserine- $O$ trans-succinylase .Many mutants of Salmonella typhimurium which excrete methionine and are resistant to $\alpha$-methylmethionine do not show cross-resistance to ethionine and norleucine and such mutations map very close to the met-A gene (the structural gene for homoserine- $O$-trans-succinylase (Smith \& Childs, I966) and it is proposed that they contain an altered enzyme insensitive to both methionine and $\alpha$-methylmethionine.

$\alpha$-Methylmethionine may have other effects. Thus the inability of small concentrations of homocysteine to annul inhibition of growth suggests that $\alpha$-methylmethionine may influence the uptake of homocysteine. Cystathionine, an earlier methionine precursor, is more effective than homocysteine and possibly gets into organisms without interference from the analogue.

The formation of methionine from D-methionine, DL-homocysteine, and $N$-acetylmethionine probably accounts for the effect of these compounds on homoserine- $O$ trans-succinylase. Homocysteine is readily methylated to methionine by intact organisms of Escherichia coli (Gibson \& Woods, 1960), methionine-requiring mutants of $E$. coli will utilize D-methionine for growth (Cooper, 1966), while methionine (identified by paper chromatography) is readily produced from $\mathrm{N}$-acetylmethionine by intact organisms of $E$. coli strain PA I5 (unpublished observations).

It has been previously observed that methionine is much more effective as an inhibitor of homoserine- $O$-trans-succinylase when intact organisms of Escherichia coli are tested than when ultrasonic extracts are used. It is probable that intact organisms convert methionine to $S$-adenosylmethionine which is a co-inhibitor of the enzyme (Lee, Ravel \& Shive, I966). The inhibition of growth and enzyme activity by very low concentrations of $\alpha$-methylmethionine implies that this compound also may form an $S$-adenosyl derivative active as a co-inhibitor.

Limitation of methionine by the feedback effect of the $\alpha$-methylmethionine was probably responsible for the inhibition of $(a)$ bacteriophage formation in Escherichia coli $\mathrm{HfrH}$, and (b) phenylalanine incorporation in $E$. coli PA I5. Apart from its effect on methionine formation the analogue did not apparently influence protein synthesis. Thus it did not replace methionine in protein synthesis (Table 5) nor did it interfere with incorporation of labelled methionine (unpublished observations). 
The author is grateful to Dr D. A. Smith and Mr D. A. Lawrence for helpful discussions during this work and to Miss Elaine Warden for expert technical assistance.

Since this work was completed Schlesinger (1967) has published results and conclusions very similar to those in the present paper.

\section{REFERENCES}

COOPER, S. (1966). Utilization of D-methionine by Escherichia coli. J. Bact. $92,328$.

GiBson, F. \& WooDs, D. D. (1960). The synthesis of methionine by suspensions of Escherichia coli. Biochem. J. 74, 160.

Gross, D. \& TARVER, H. (I955). Studies on ethionine. IV. The incorporation of ethionine into the proteins of Tetrahymena. J. biol. Chem. 217, I69.

LaWrence, D. A., Smith, D. A. \& RowbURY. R. J. (1967). Regulation of methionine synthesis in Salmonella typhimurium: mutants resistant to inhibition by analogues of methionine. Genetics (in the Press).

LEE, L. W., RAVEL, J. M. \& SHIVE, W. (1966). Multimetabolite control of a biosynthetic pathway by sequential metabolites. J. biol. Chem. $241,5479$.

LeVin, A. P. \& Hartman, P. E. (1963). Action of a histidine analogue, $1,2,4$ triazole-3-alanine in Salmonella typhimurium. J. Bact. 86, 820.

LeVIN, A. P. \& MAGASANIK, B. (1959). Effect of guanine deprivation on enzyme formation. Fedn. Proc. 18, 272.

LEWIS, D. (1963). Structural gene for the methionine activating enzyme and its mutation as a cause of resistance to ethionine. Nature, Lond. 200, $15 \mathrm{I}$.

MOYED, H. S. (196r). Interference with feedback control of enzyme activity. Cold Spr. Harb. Symp. Quant. Biol. 26, 323.

MUNIER, R. \& COHEN, G. N. (1959). Incorporation d'analogues structuraux d'amino-acides dans les protéines bactériennes au cours de leur synthèse in vivo. Biochim. Biophys. Acta 31, 378.

RICHMOND, M. H. (1960). Incorporation of para-fluorophenyl-alanine into exopenicillinase of Bacillus cereus 569/H. Biochem. J. 74, 8 P.

RowBURY, R. J. \& WoODS, D. D. (1961). Further studies in the repression of methionine synthesis in Escherichia coli. J. gen. Microbiol. 24, 129.

ROWBURY, R. J. \& WOODS, D. D. (1964). Repression by methionine of cystathionase formation in Escherichia coli.J. gen. Microbiol. 35, 145.

ROWBURY, R. J. \& WoODS, D. D. (1966). The regulation of cystathionine formation in Escherichia coli. J. gen. Microbiol. 42, 155 .

SCHLESINGER, S. (1967). Inhibition of growth of Escherichia coli and of homoserine- $O$-trans-succinylase by $\alpha$-methyl-methionine. J. Bact. $94,327$.

SмrTH, D. A. \& ChILDS, J. D. (1966). Methionine genes and enzymes of Salmonella typhimurium. Heredity 2I, 265. 